\title{
Environmental Crisis of Rangpur City Corporation: A Case Study in Radhakrishnapur and South Binnatari Village
}

\author{
A. T. M. Zinnatul Bassar, Md. Ahoshan Habib \\ Department of Disaster Management, Begum Rokeya University, Rangpur, Bangladesh
}

Email address:

bassar@brur.ac.bd (A. T. M. Z. Bassar), sajibdm04@gmail.com (Md. A. Habib)

\section{To cite this article:}

A. T. M. Zinnatul Bassar, Md. Ahoshan Habib. Environmental Crisis of Rangpur City Corporation: A Case Study in Radhakrishnapur and South Binnatari Village. International Journal of Environmental Protection and Policy. Vol. 5, No. 1, 2017, pp. 12-18. doi: 10.11648/j.ijepp.20170501.12

Received: January 7, 2017; Accepted: January 18, 2017; Published: February 23, 2017

\begin{abstract}
This research studies the environmental crisis in villages Radhakrishnapur and South Binnatari under Rangpur City Corporation. Although the villages are under City corporation area, these are deprived of the opportunities and access available for City Corporation. Moreover the areas are regularly being affected by natural disasters as flood and river bank erosion. People of the community gave a mixed perception on "Monga", whether it is prevailing or not and they defined it by their own way. People of the community have silent conflict with the Army body on land acquisition issue. People have less access to work and a portion migrates to other areas, either inside the city or other cities to find out alternative sources of income. The researchers tried to explore the problems and crisis of the people of these two villages so that further initiatives to mitigate these can be taken.
\end{abstract}

Keywords: Environmental Crisis, Flood, River Bank Erosion, Monga

\section{Introduction}

Environmental crisis is a contemporary issue of the present world. It indicates mainly environmental problems such as air pollution, water pollution, massive level of land degradation, damage crops and vegetation etc. If we explore the causes of environmental crisis, we will likely discover that the root cause is not in overpopulation [1] nor it is in technology [2], it can be regarded as a crisis for humanity and modern civilization as the "bedrock assumptions of our civilization are increasingly at odds with the world we now inhibit" [3]. This crisis has catastrophic effect including increased rate of health diseases, desertification and loss of plant species. This often hindered cures for diseases. Radhakrishnapur (Ward No-12) and South Binnatari (ward no-11) of Rangpur City Corporation are vulnerable to many environmental problems. The villagers are mainly faced flood as well as drought, cold wave, earthquake etc. Flood affects them economically mostly. They can't go outside for work. They become workless due to flood. The local communication system destroys by flooding. Roads go under water and create water logging. Maximum people of this locality are hand to mouth earners. So they have to go outside every day for works. Days after days people victim to economic damage.

The monsoon season is followed by a prolonged dry season, where lack of appreciable rainfall and almost continuous evaporation from the top soil give rise to aridity and subsequent (phonological) moisture stress [4], [5]. The rivers both big and small gradually became incapable of draining the huge quantity of silt-laden runoff passing through them during the monsoon period and cause floods [6]. The catchment area of the major rivers is about 1.65 million square $\mathrm{km}$ of which only 7.5 percent lies within the border of Bangladesh [7] that generates 1200 $\mathrm{km} 3$ of run-off annually, only 10 percent of which is generated within Bangladesh. In addition to vast quantities of water, these rivers carry about 1.1 billion tons of sediment every year [7], [6] and are responsible for the prevalence of flooding and riverbank erosion in Bangladesh [9]. Accepting a very few studies [10], [11], [12], [13], [14] most of the research on river bank erosion impact dealt with geomorphic phenomena in a very particularistic manner. The combination of the large discharges and heavy sediment loads with high water 
content from the annual wet monsoon, a low degree of compaction, and a large amount of runoff materials result in highly variable and dynamic channel morphologies to adjust their bed configurations. The river channel may shift laterally by more than 300 meters [15] in any season. The rivers are braided and still undergoing erosion-accretion cycle, resulting in severe erosion in one bank and accretion in the other [16]. Beside the hydro-geophysical reasons, developmental factors also exacerbate the disasters and climate change impacts. These include: population density, high poverty, income inequality, fragile infrastructure, limited integration of disaster risk into national and local planning and low human development progress [17]. In recent years "the urban environment" has become a coherent concept, a political issue and a matter for the attention of the research councils' [18].

\section{Methodology}

This paper is created mainly based on primary data including direct survey on the villagers. Here, the villages Radhakrishnapur and South Binnatari were selected purposively from Rangpur City Corporation as these two are familiar disaster affected areas of the locality those are

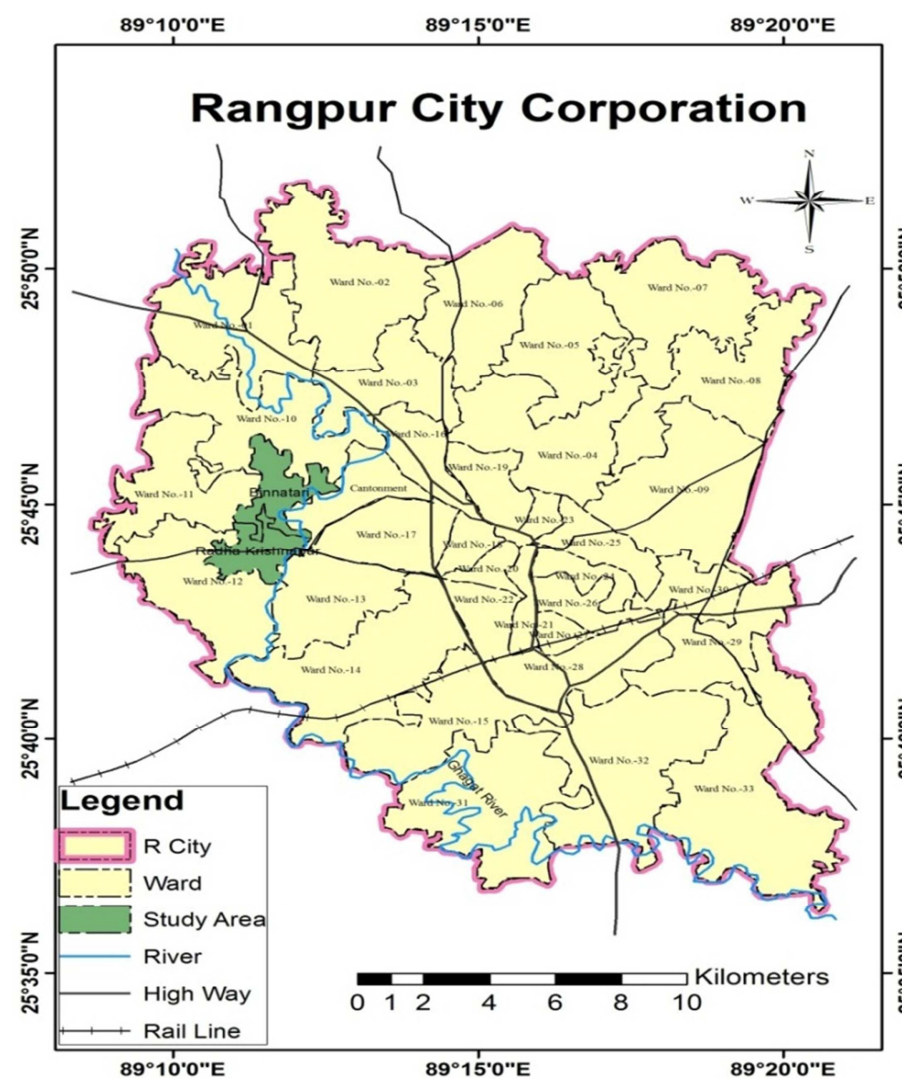

adjacent to Ghaghat River in the south-west part. 40 people from each village were selected randomly to gather information on environmental crisis where people of different ages were included. A transact walk around the village helped to achieve knowledge and information on hazards and disasters as well as socioeconomic condition of the people. Some people were informally interviewed in a friendly way to gather information on the actual scenario of the crisis related to environment. Some others data are collected from different NGO's working on those villages.

Study Area

Radhakrishnapur (Ward No-12) and South Binnatari (Ward No-11) are two underdeveloped localities among the 33 wards of Rangpur City Corporation. These two villages are under Rangpur Sadar than a located adjacent to Rangpur cantonment area. Main Ghaghat River is flowing to the north-eastern part of these two villages and a branch of Ghaghat is flowing inside the south-western part and it ended in the west part connecting Razendrapur village. A part of the South Binnatatari is located to the northern part of Radhakrishnapur. The village named Keranirhat is to the northern part and village named Nazirerhat is to the western part of these two villages.

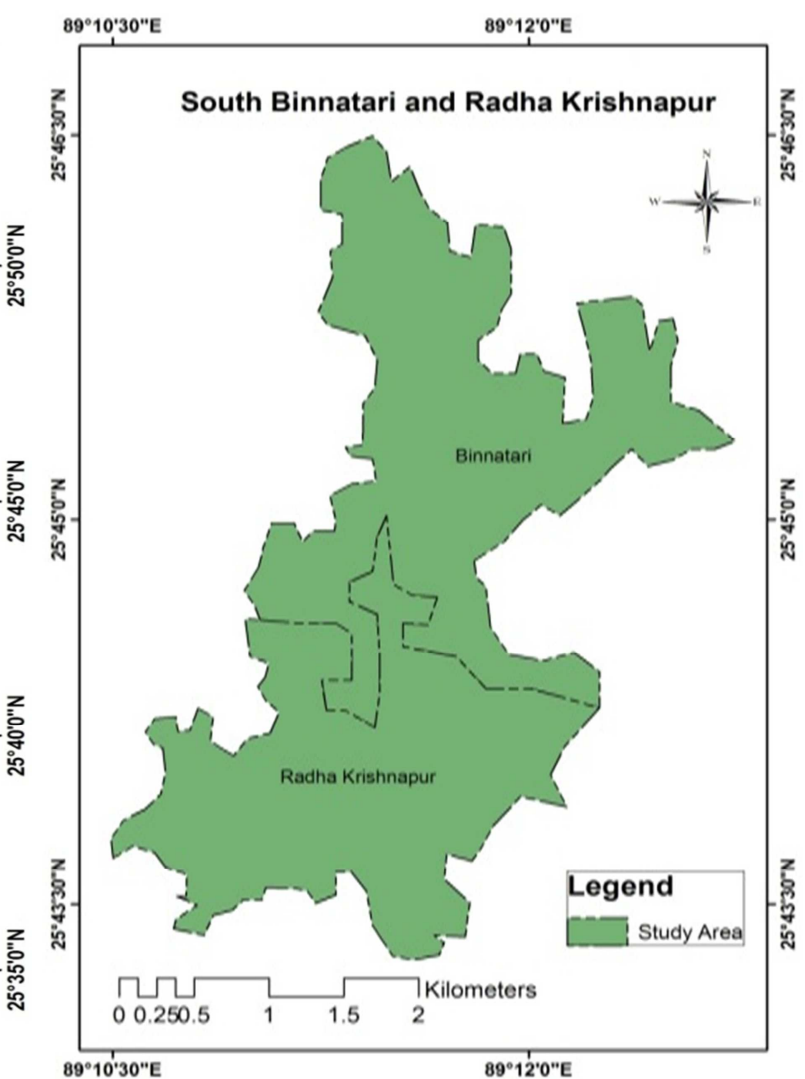

Figure 1. Map of the study area using Arc GIS 10.1 software.

\section{Result and Discussion}

This paper is prepared for the assessment of environmental crisis of Radhakrishnapur (Ward No-12) and South Binnatari (ward no-11) of Rangpur City Corporation. We surveyed a total on 80 people where 40 people of each village were included. Where, among the respondents in Radhakrishnapur village male were 26 and female were 14 . Among them 10 male and one female were educated. 10 men and 6 women 
took primary education and 6 men and 6 women took secondary education. In the South Binnatari village numbers of male respondents were 22 and female were 18 . Of them 14 male and no female were educated.

\subsection{Socio-demographic Information of the Study Area}

The study clearly shows the socio-demographic information shown in Table-1 and Table- $2.65 \%$ of the respondents were male and rests $35 \%$ were female. Among the total 80 respondents $30 \%$ were illiterate, $40 \%$ have primary level education those completed at least class five education, other $30 \%$ have secondary level education who have completed at least class ten education and some of them went for further education. Of the uneducated people $83.3 \%$ were men and rest $16.7 \%$ were female. Of the respondents who got their primary education $62.5 \%$ were male and $37.5 \%$ were female. $50 \%$ of the people who took their secondary level education were male and other $50 \%$ were female. The age class of the respondents was segmented into four groups. Of the respondents $10 \%$ are in the group class 25 or below, $45 \%$ were of the age class 26 to 45 years, 46 to 65 years of age class contained $45 \%$ of the total respondents and there was no single person of age class 66 years or above. Of the people among the age class 25 or below, $50 \%$ were male and rest $50 \%$ were female. $55.5 \%$ of the people of age class 26 to 45 were male and rest other $44.5 \%$ were female. The age class of 46 to 65 years contained $77.8 \%$ male and $22.2 \%$ female.

Table 1. Demographic information.

\begin{tabular}{lllllllll}
\hline \multirow{2}{*}{ Gender } & \multicolumn{1}{l}{ Education } & \multicolumn{5}{l}{ Age (years) } \\
\cline { 2 - 8 } & illiterate & primary & secondary & $\mathbf{0 - 2 5}$ & $\mathbf{2 6 - 4 5}$ & $\mathbf{4 6 - 6 5}$ & $\begin{array}{l}\text { 66 and } \\
\text { Above }\end{array}$ \\
\hline Male & 20 & 20 & 12 & 4 & 20 & 28 & 0 \\
Female & 4 & 12 & 12 & 4 & 16 & 8 & 0 \\
\hline
\end{tabular}

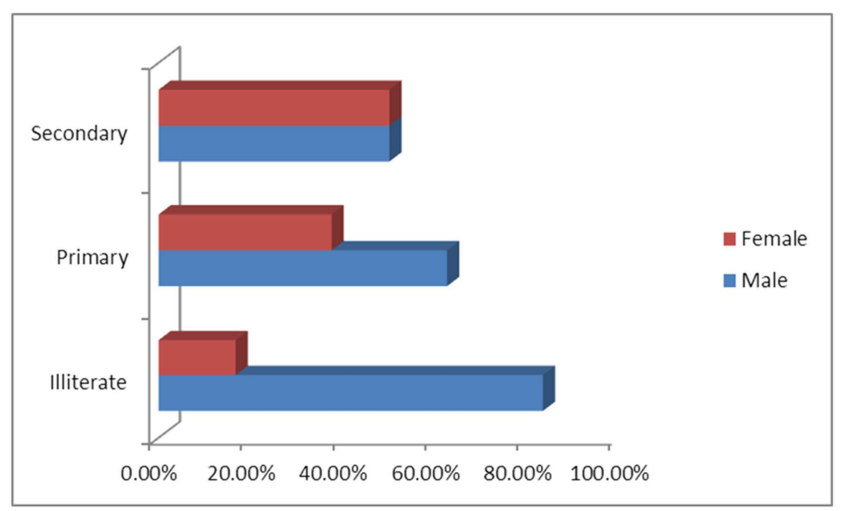

Figure 2. Educational status.

There are many people with various professions in the villages. Among the 80 surveyed people $65 \%$ were male and of them $32.5 \%$ were engaged in farming activities, $20 \%$ were businessmen and 5\% were rickshaw puller and rest $7.5 \%$ were engaged in road repairing work. Women other than housewife were not found.
Table 2. Livelihood status.

\begin{tabular}{llllll}
\hline Gender & Farmer & Housewife & Businessman & $\begin{array}{l}\text { Rickshaw } \\
\text { Puller }\end{array}$ & $\begin{array}{l}\text { Road } \\
\text { Repairing }\end{array}$ \\
\hline Male & 26 & 0 & 16 & 4 & 6 \\
Female & 0 & 28 & 0 & 0 & 0 \\
\hline
\end{tabular}

When there is no work for the farmers in the AshwinKartik (September-October) month, some farmers try to find temporary job and that time they become involved in repairing houses by thatching materials, especially by straw or bamboo, some are involved in repairing of roads, some go to work in city shops and few go to others cities like Dhaka, Sylhet, Comilla, Chandpur, Feni etc. to earn money.

Table 3. Status of migrant people in the Rangpur city and other cities.

\begin{tabular}{ll}
\hline \multicolumn{2}{l}{ Work outside of the home (cash / in kind / exchange labour) } \\
\hline $\begin{array}{l}\text { In village, commune or district } \\
\text { i) Digging or carrying soil in }\end{array}$ & Migrant \\
commune, village or district & Adult men \\
$\begin{array}{l}\text { ii) Extra transplanting / harvest } \\
\text { work inside village }\end{array}$ & Wives, adult and adolescent \\
iii) New or extra transplanting / & daughters \\
harvest work outside village & Adult and adolescent daughters \\
Other town or city & Migrant \\
i) Domestic work & Adolescent daughters and young \\
ii) Construction work & women \\
iii) Digging or carrying soil & Adult \& young men and women \\
iv) Garment factories & Adult men \\
v) Begging & Adolescent daughters and young \\
\hline
\end{tabular}

The field data shows that; none of the beneficiaries used only brick for the walls of their houses. About 32 had the houses made of bamboo. Among others 10 had the houses made of straw, 16 had houses made of jute stick and 22 had the houses made of tin.

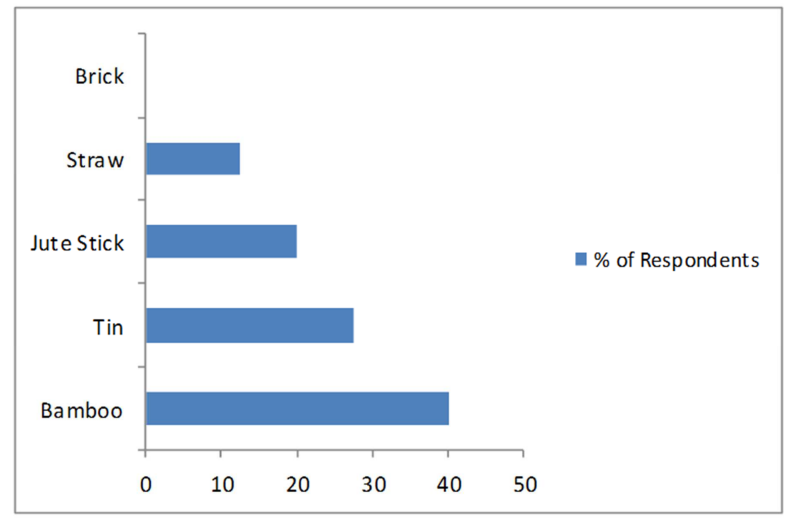

Figure 3. Household materials of the respondents.

This community is vulnerable to many hazards like drought, flood, river bank erosion, cold wave, heat wave, storms, monga etc. From our direct observation we found that they are most affected by flood that occurs middle of the Bengali month of Jaishtha to Vadro. Severe flood occurs mainly Ashar and Shraban month. It causes damage of crops, roads, culverts, houses and losses of cattle and fisheries. People can't go outside for several days. As a result they 
remain workless. They have to use their reserved money. Students can't go to school. Some people loss their habitat temporarily and migrate to high land. Secondly, they become affected by drought that occurs middle of Magh $\left(10^{\text {th }}\right.$ month in Bengali calendar) to middle of Baishakh $\left(1^{\text {st }}\right.$ month of Bengali calendar). But drought becomes destructive mainly
Falgun $\left(11^{\text {th }}\right.$ month in Bengali calendar) and Chaitra $\left(10^{\text {th }}\right.$ month in Bengali calendar). It causes severe crop damages, soil fertility loss, vegetation loss, air pollution, air borne diseases (like asthma, bronchitis etc.), skin diseases etc. During drought maximum people become unemployed.

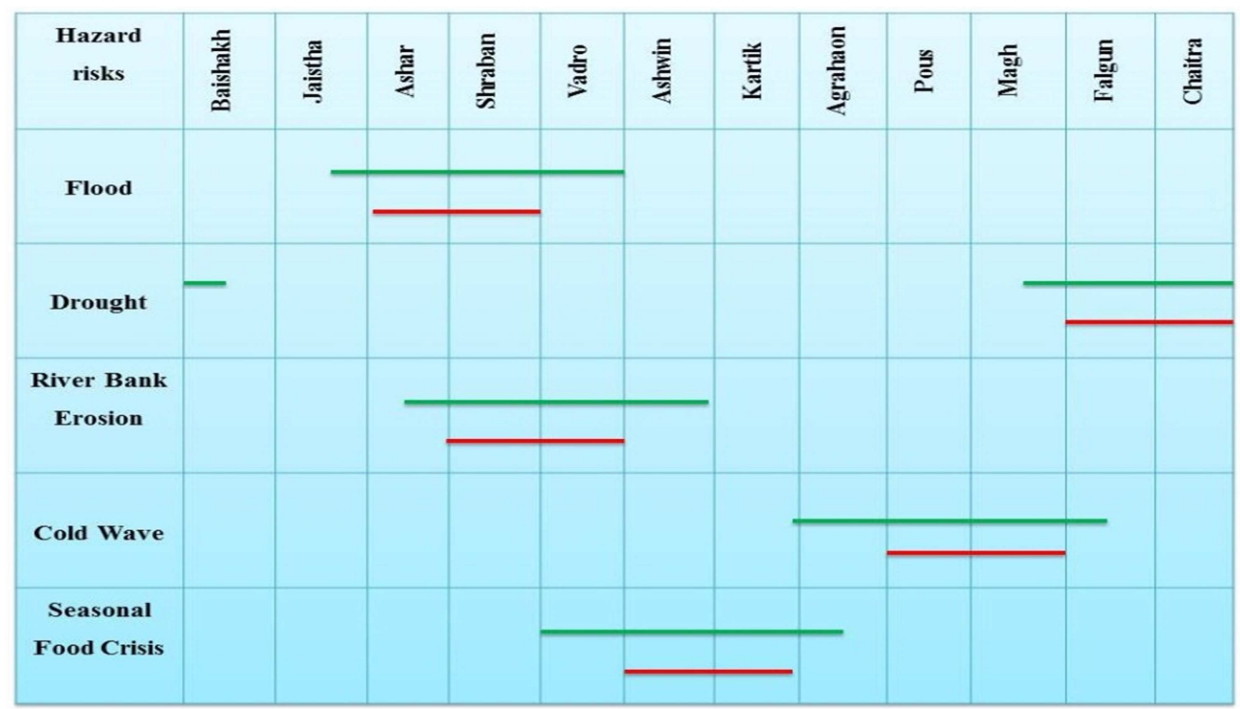

Figure 4. Seasonal disaster risk calendar of the people of Radhakrishnapur and South Binnatari based on Bengali Month prepared by gathering primary data.

Here in the table, Red colors indicate high risky time to disaster. Green color indicates less risky time to disaster. The purpose of preparation of the seasonal calendar is to help in getting ready for upcoming disasters in the village community as well as to help identifying mitigation time of disasters. So, preparing this calendar might play important role to confront with disasters in this village community.

\subsection{Flood and River Bank Erosion in the Area}

Main Ghaghat River is flowing to the north-eastern part of these two villages and turning in the east side to the west a channel of Ghaghat is flowing inside the south-western part and it ended in the western part connecting Razendrapur village. A part of the South Binnatatari is located to the northern part of Radhakrishnapur.

According to the people whenever there is intense rainfall in the Ashar-Srabon (July-August) month, water from the main Ghaghat River enters into the channel. Most of the times of the year the channel remain dead. The excessive water from the main Ghaghat enters into the channel and whenever a large water body exceeds the carrying capacity of the channel, it creates flood for the locality.

Two years ago an embankment with high slope was built in the north-eastern part of the main Ghaghat River which is exactly south-western part of the cantonment area. Due to having high slope hindrance, water body that would regularly hit and run through southern part is striking the northern side and thus bank of the northern side is being eroded and a large part of this portion is already object of river bank erosion. If this happens in a regular basis, it will create a great loss.
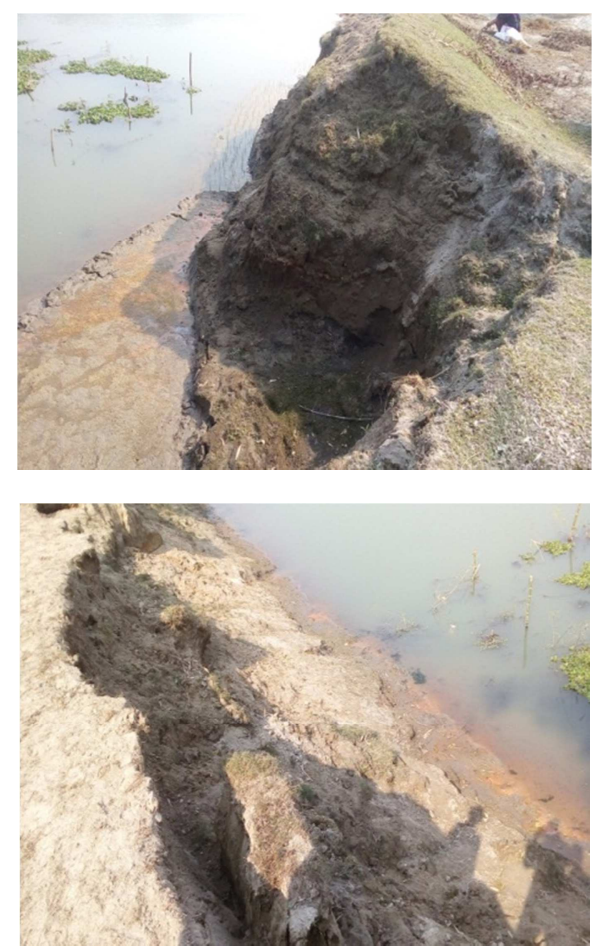

Figure 5. River bank erosion in the locality.

\subsection{Mixed Perception on "Monga" in the Locality}

The perception of monga varied people to people in the locality. Respondents were asked about the concept of monga, the question was actually "what is monga?". Some people answered monga as the period of unavailability of 
work, some said the time when they gather food by doing loan. Others answered monga as unavailability of work induced unavailability of food. According to Razen Chandra, a 38 years old farmer who works on others field demarcated monga as "whatever the work you give me, I can do. I have no place to work and that's why I can't work and cannot gather food. Monga prevails in my family when I suffer lack of work." The question whether Monga is available in the study area or not was answered by the respondents. $40 \%$ of the people said that there is no monga in this region, $45 \%$ answered of having monga and rest 5\% did not know the answer. $48 \%$ of the people who said that there was monga said that the monga is seasonal and it occurs in the disaster period especially in the flood period that is induced by over rainfall and sometimes due to overflow of Ghaghat River induced by rainfall. Rest $52 \%$ said that it happens all over the year. The people who agreed of having monga said that it occurs in Vadro to middle of Agrahaon month. Intensity of monga increases in Ashwin and Kartik month.

\subsection{Conflict between Army and Local People on the Land Acquirement Issue}

As the area is very next to cantonment, army has acquired the land by a rule passed by caretaker government of 200708. According to the rule, the areas excluding the households were acquired by the cantonment. People said that they were paid nominal amount for their land ranging between 5000 taka to a maximum of 22000 taka per 0.01 acre considering the distance from the cantonment and quality of land. According to the people, actual amount of the lands are two to three times of the paid value. Some people even not yet paid their value measured by the army body. People are asked to cultivate for the last time in December-January (Ograhayon-Poush) season 2016 although all the people are not paid their money valued for land. People lost their arable lands on which their livelihood mainly depended and in place they were paid nothing but some money. Thus the people who gathered their capital by cultivating their own land and those who depended by working on others field are suffering for lack of employment. Most of the people said that if there would have any permanent working source such as establishing of any industry in place of losing the lands for making source of employment would be a great solution to get rid of the problem. Community people think that there is a great possibility of rising up the monga problem as they are lacking employment and as per the perception of most of the people monga is directly linked to the lack of work to live on. Monga was available 5 to 7 years ago when drought problem was severe in the northern part of Bangladesh. Due to climate change, the drought situation has been reduced and people were prepared to completely recover monga. Some people think that now a day's monga have been due to lack of work in flood situation. They used to store produced rice, paddy etc. and in the disaster period they got used to either selling to gather capital or using for their own purpose. After acquiring the lands, people will not be able to cultivate the lands and thus their direct and indirect earning sources will be diminished. According to most of the people this will induce monga situation. During the flood season people of the community used to take their cattle to the high elevated dam area but this area is now acquired by army and a recreational park named "Proyas" has been built here. Army body does not permit local people to use this area for indigenous purpose.

\subsection{Capacity Assessment versus Environmental Crisis}

People of the area undertake preparedness measures based on their realistic experiences. Such as Mobile Chula, storing dry food like chira, muri, dry fish etc., fuel for cooking, preserving fodder and poultry feed and creating chhika (an utensil made by jute fiber used for preserving pots that contains different materials by hanging with the inside part of the roof). During flood period women, in addition to their daily usual activities, play a foremost part in taking care of children, sick and elderly people as well as livestock. They also provide mental support to the family members and making initiatives for collecting relief materials, food and fuel. Generally, women hardly ever attain any recognition for such role. In the period of flood, people use sandbag for protection of river embankment to save themselves. At present, raising of roads, tube-well, toilet and homestead are being done by people as the region is low lying. In case of severe drought, people are using biotic fertilizer to content soil moisture. Mulching practice, using wet grasses, green leaves on soil to preserve soil moisture against drought situation. Community people, taking assistance from different nongovernmental organizations arrange mock drill for raising awareness among the people. $60 \%$ people said that they know the agricultural calendar and aware of the changing agricultural calendar and cultivation pattern and now a day's they are selecting short term crop varieties and others said that they didn't know about it.

\subsection{Local Coping Mechanisms and Adaptation Strategies}

Local people are trying to cope with extreme weather events with some strategies. They are planting trees along the bank of the river. It slows down the river bank erosion and flood water. They cultivate floating bed crops or vegetables on water logging lands. Farmers produce pumpkin, water gourd, turmeric, chichinga, lalshak, puishak (local name), ladies finger, tomato etc. The growth of vegetable is very high and production is almost double compared to normal cultivation in land. They raise road and bank of rivers to protect from flood. Farmers bring the new varieties of hybrid crops to coping with hazards. Some rice species Such as BINA-7, Moyna, BRI-28, HIRA-2, Dhani Gold are harvested before upcoming flood. Farmers cultivate some new maize species such as 999, 982, 981, and 244 that are resistant strong winds and high production. Farmers cultivate some new potato species such as Cardinal, Holender, Pertonis and meridian that are harvested before coming cold wave and high production than other species. These new species contribute to reduce monga in the village. 


\subsection{Social Response of the Community}

Before converting into the Rangpur city corporation in 2012, the study areas were under Rangpur Sadar upazilla. Most of the respondents said that no nongovernmental organization but the government is active to help the poor community. According to the people some governmental and nongovernmental organizations help the community to cope with environmental crisis but the helps come mainly during and post disaster phase. United Nations Development Programme (UNDP) organized "Gonoshikkha" programme two to three years ago and the main purpose of the programme was to give fundamental signature knowledge as well as to aware people to face disasters. Most of the people said that after converting into City Corporation, the assistance from the local government had been reduced, especially they noticed and alleged that local counselor did not meet them last two years even though they had been facing different crisis related to environment.

\subsection{Environmental Crisis Induces Social Crisis}

Although women work with the men step by step, they do not get equal esteem. During disaster period, taking preparation and mitigating activities for the disaster to emergency response and recovery, women play major role but they are given minor priority in decision making for the family. Male members of the family take decisions and most of the times even the female members are not asked to give any opinion. $65 \%$ of the people said that no opinion is taken from the female members, they are just asked to do the task and perform the decision taken by male members. This absence of social equality induces social crisis. Other $25 \%$ said that opinions of the female members are heard but these are not being taken as consideration in the implementation. The rest $10 \%$ said that they don't have any idea. People are paying high interest on loan that they are taking from rich people and nongovernmental organizations and they are being castigated whenever they are being unable to pay the liability in time. In the locality, BRAC and ASA work for the community, especially provide loan during and immediately after disaster. 42 years old Shirina Begum said that she has to pay 200 taka interest per month for every 1000 taka they lend from the Mahajan, the elite people of the community who lend money at high interest rate. Finally, whenever they are unable to pay their liability are being provoked to sell their cattle or stored food and thus by selling these they are paying their debt. According to the people the characters of Mahajan and nongovernmental organizations are more or less the same. Community participation in various awareness programs is very low. Poor people are not actively involved in campaigning awareness and capacity building programmes. Different community oriented capacity and awareness building programmes were thrown by nongovernment organization, especially by UNDP and they involved people. $35 \%$ of the respondents said that they were involved in such programmes (workshop and training) and other $65 \%$ said no.

\section{Conclusion}

As the citizen of city corporation area, local people are lacking proper opportunities. They have to live under standard condition of life with floods, storms, cold waves, droughts, earthquakes etc. Roads and transportation system are very poor as a city corporation area. They have no sufficient facilities of relief activities during floods and allotment of necessary warm cloths during extreme cold in winter season. The researchers became very frustrated to see their extreme poor life conditions. So City Corporation authority should concentrate on developing their life condition otherwise it will be ill-judged with them or deprived of them from their fundamental rights.

\section{References}

[1] Erlich, P., 1968/1997. The population bomb, Cutchogue, NY: Buccaneer Press.

[2] Borgmann, A., 1984. Technology and the character of contemporary life: A philosophical inquiry. University of Chicago Press.

[3] Dumonaski, D., 2001. A humanity crisis. Presentation at Global Environmental Action Conference, Tokyo, October 12, 2001. Available:

http://ourstolefuture.org/Commentary/DD/20011012DDhumanitycrisis.htm.

[4] Asaduzzaman, M., M. Reazuddin, and A. U. Ahmed (eds.), 1997: Global Climate Change: Bangladesh Episode. Department of Environment, Ministry of Environment and Forest, Dhaka, 40pp.

[5] Karim, Z., Hussain, Sk. G. and Ahmed, A. U., 1998, "Climate Change Vulnerability of Crop Agriculture", in S. Huq, Z. Karim, M. Asaduzzaman and F. Mahtab (Eds.), Vulnerability and Adaptation to Climate Change for Bangladesh, Kluwer Academic Publishers, Dordrecht. pp 39-54.

[6] Flood Response Preparedness Plan of Bangladesh, June 2014: Department of Disaster Management, Bangladesh.

[7] Sarker, M. H., Hugue, I., Alam, M. and Koudstaul, R., 2003, Rivers, Chars and Char Dwellers of Bangladesh, Int. J. of River Basin Management, 1 (1): 61-80.

[8] EGIS, 2000, Riverine Chars in Bangladesh: Environmental Dynamics and Management Issues, the University Press Limited, Dhaka, Bangladesh, pp. 88.

[9] Elahi KM, John RR and Rogge JR. 1990. Riverbank erosion, flood and population displacement in Bangladesh: A report on the riverbank erosion impact study, Dhaka: Riverbank Erosion Impact Study (REIS), Jahangirnagar University (JU).

[10] Haque CE. 1988. Impacts of Riverbank erosion Hazard in Brahmaputra Jamuna Floodplain: A study of population displacement and response strategies. PhD Thesis, Department of Geography, University of Mintoba, Canada.

[11] Zaman MQ. 1986. Rural Bastees-economicand political dynamics of Accretiona and depositional and development land erosion and flood hazard hazards in Bangladesh, Dhaka: Jahangirnagar University, 16p. 
[12] Elahi, K. M., 1972, Urbanization in Bangladesh: A Geodemographic Study, Oriental Geographer 16 (1): 39-48.

[13] Islam MS. and Islam AMZ. 1985. A brief account on Bank erosion, Model, Studies and Bank Protective Works in Bangladesh, REIS Newsletter 2: 10-13.

[14] Rogge JR. 1991. Individual and institutional response to riverbank erosion hazards. In: KM Elahi KS. KS Ahmed and M Mafizuddin (eds.), Riverbank Erosion, Flood and Population Displacement in Bangladesh. Dhaka: REIS, JU.

[15] Haque, C. E., and Hossain, Z., 1988, Riverbank Erosion in Bangladesh, Geographical Review, 78 (1): 20-31.
[16] Rashid, H. E., 1991. Geography of Bangladesh (2nd Edition), University Press Limited, Dhaka, pp. 545.

[17] Ahmed, A. U., 2013. Facing an Uncertain Future Under Global Environmental Change: How Bangladesh Will Address Vulnerabilities? Centre for Global Change (CGC), Dhaka.

[18] Petts J, Owens S and Bulkeley H, 2005 Discussion Paper for Seminar 6. ESRC Transdisciplinary Seminar Series, Knowledge and Power: Exploring the Science/Society Interface in the Urban Environment Context. Available from: http://www.cert.bham.ac.uk/urbanenvironment/index.htm [Accessed July 2005]. 